titanium; ammonium phosphate for germanium and vanadium; ammonium perchlorate for titanium).

A nonspecific absorbance for $\mathrm{MgCl}_{2}, \mathrm{CaCl}_{2}, \mathrm{KCl}$, and $\mathrm{NaCl}$ was observed for the 265.1-nm wavelength (germanium) and was removed by the addition of $0.6 \mathrm{M}$ of nitric acid.

The working range of all examined elements was between $0.1-0.5 \mathrm{ppm}$. The calibration graphs were linear up to a concentration of approximately $0.4 \mathrm{ppm}$. The sensitivities ( $1 \%$ absorption) were: $0.015 \mathrm{ppm}$ for germanium, $0.03 \mathrm{ppm}$ for vanadium, and $0.08 \mathrm{ppm}$ for titanium.

The addition of 2-pyridylphosphinic acid reduced the interference of sulfuric acid on germanium and enhanced the signal of vanadium in the presence of nitric acid but decreased the signal of titanium.

\section{LITERATURE CITED}

(1) Hermanowicz, W:; Dożańska, W.; Dojlido, J.; Koziorowski, B. "Fizyczno-chemiczne badanie wody i s̉ciekôw", Arkady: Warsaw, 1976; p 392.

(2) Rudenko, N. P. Tr. Kom. Anal. Khim., Akad. Nauk. SSSR, 1963, 14, 209.

(3) Lyle, S. J.; Shendrikar, A. D. Anal. Chim. Acta 1965, 32, 575.

(4) Lyle, S. J.; Shendrikar, A. D. 1966, 36, 286.

(5) Alimarin, I. P.; Sokolova, I. V.; Smalina, E. V.; Firsowa, G. V. Zh. Anal Khim. 1970, 25, 2287

(6) Alimarin, I. P.; Sokolova, I. V.; Smalina, E. V. Vesti MGU 1668,67

(7) Shimomura, S.; Sakurai, H.; Morita, H. Anal. Chim. Acta 1978, 96, 69.

(8) Jakubiec, R.; Boltz, D. F. Anal. Chem. 1969, 41, 78.

(9) Ohta, K.; Suzuki, M. Anal. Chem. Acta 1979, 104, 293

(10) Doll, W.; Specker, H. Fresencus' Z. Anal. Chem. 1958, 161, 354

(11) Schüller, H. Mikrochim. Acta 1956, 393

(12) Gorlushina, V. G.; Biriukova, E. I. Zh. Anal. Chim. 1969, 24, 580

(13) Mulford, C. E. At. Absorpt. Newsl. 1966, $5,88$.

(14) Zolotov, I. A.; Sizonlenko, N. T.; Zolotovickaja, E. S.; Jakovenko, E. 1. Zh. Anal. Chim. 1969, 24, 20

(15) Kamiya, A. Eisei Kagaku 1975, 21, 267; Anal. Abstr. 1976, 30, 6H9

(16) Jakublec, R, Boltz, D. F. Anal, Lett. 1968, 1, 347.

(17) Sutter, E. M.; Leroy, M. J. Anal. Chim. Acta 1978, 96, 244.
(18) Kirkbright, G. F.; Smith, A. M.; West, T. S.; Wood, R. Analyst (London) $1969,94,755$.

(19) Katskov, D. A.; Kruglikova, L. P.; L'vov, B. V. Zh. Anal. Khim. 1975, $30,238$.

(20) Drwiega, J.; Jedrzejewska, H.; Malusecka, M. Chem. Anal. (Warsaw) $1975,20,539$

(21) Damiani, M.; Tamba, M. G.; Bianchi, F. Analyst (London) 1975, 100, 643.

(22) Cobb, W. D.; Foster, W. W.; Harrison, T. S. Anal. Chim. Acta 1975, 78, 293.

(23) Lagas, P. Anal. Chim. Acta 1978, 98, 261.

(24) Fuller, C. W. Anal. Chim. Acta 1976, 81, 199

(25) Clonl, R., Mazzucotelli, A., Ottonello, G. Anal. Chim. Acta 1976, 82, 415

(26) Frech, W.; Cedergren, A. Anal. Chim. Acta 1976, 82, 83.

(27) Smeyers-Verbeke, J.; Michotte, Y.; Van den Winkel, P.; Massart, D. Anal. Chem. 1976, 48, 125.

(28) Walsh, P. R.; Fasching, J. L.; Duce, R. A Anal Chem 1976, 48, 1014

(29) Woodis, T. C., Jr.: Hunter, G. B.; Johnson, F. J. Anal. Chim. Acta, 1977 90,127

(30) Yasuda, S.; Kakiyama, H. Anal. Chim. Acta, 1977, 89, 369.

(31) Nakahara, T.; Chakrabarti, C. L. Anal. Chim. Acta, 1979, 104, 99.

(32) Geladi, P.; Adams, F. Anal. Chim. Acta 1978, 96, 229.

(33) Johansson, K.; Frech, W.; Cedergren, A. Anal. Chim. Acta 1977, 94, 63.

(34) Studnicki, M. Anal. Chem. 1979, 51, 1336.

(35) Syty, A. CRC Crit. Rev. Anal. Chem. 1974, 4(2), 155

(36) Pritchard, M. W.; Reeves, R. D. Anal. Chim. Acta 1976, 82, 103.

(37) Frech, W.; Cedergren, A. Anal. Chim. Acta, 1977, 88, 57.

(38) Szczepaniak, W.; Siepak, J. Wiad. Chem 1975, $29,193$.

(39) Karmiñski, W. Studnicki, M., unpublished results, NMR 'H HP 5.58 ppm, $J_{\mathrm{HP}} 884 \mathrm{~Hz},{ }^{31} \mathrm{P} \mathrm{NMR} \sim 2.1 \mathrm{ppm}$ (solvent $\mathrm{H}_{2} \mathrm{O}$, reference standard $\left.\mathrm{H}_{3} \mathrm{PO}_{4}\right)$, mp $410^{\circ} \mathrm{C}$, dec. $480^{\circ} \mathrm{C}$

'Present address: Silesiau Technical University, Institute of Chemistry and Organic Technology, 44-101 Gliwice, Poland.

Marek Studnicki ${ }^{1}$

Polish Academy of Science

Institute of Environmental Engineering

41-800 Zabrze, Poland

RECEIVED for review February 8, 1979. Resubmitted December 11, 1979. Accepted February 25, 1980.

\title{
Comment on the Prediction of Gas Chromatographic Retention Behavior with Mixed Liquid Phases
}

Sir: Recently Pecsok and Apffel (1) demonstrated that the Kovats' Retention Index of a particular solute on a binary stationary phase $I(\phi)$ could be reasonably estimated by

$$
\begin{array}{r}
I(\phi)=M(\phi) \log \left[\phi_{\mathrm{A}} 10^{\left(\mathrm{I}_{\mathrm{A}}^{0}+\mathrm{N}_{\mathrm{A}}\right) / \mathrm{M}_{\mathrm{A}}}+\right. \\
\left.\phi_{\mathrm{S}} 10^{\left(\mathrm{Is}_{\mathrm{s}}^{0}+\mathrm{N}_{\mathrm{S}}\right) / \mathrm{M}_{\mathrm{s}}}\right]-N(\phi)
\end{array}
$$

$M(\phi)=$

$$
\overline{\log \left[\left(\phi_{\mathrm{A}} K_{\mathrm{R}(\mathrm{Z}+1), \mathrm{A}}^{0}+\phi_{\mathrm{S}} K_{\mathrm{R}(\mathrm{Z}+1), \mathrm{S}}^{0}\right) /\left(\phi_{\mathrm{A}} K_{\mathrm{R}(\mathrm{Z}), \mathrm{S}}^{0}+\phi_{\mathrm{S}} K_{\mathrm{R}(\mathrm{Z}) \mathrm{S}}^{0}\right)\right]}
$$

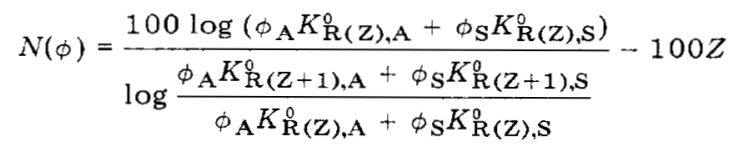

where $\phi_{\mathrm{A}}$ and $\phi_{\mathrm{S}}$ refer to the volume fraction of pure phases A and $\mathrm{S}$, respectively. $K_{\mathrm{R}(\mathrm{Z}+1)}^{0}$ and $K_{\mathrm{R}(\mathrm{Z})}^{0}$ refer to the partition coefficients of the two $n$-paraffins ( $Z$ and $Z+1$ carbon atoms) whose retention times bracket that of the solute. When differences of retention indices in the pure solvents are small, Pecsok and Apffel indicate that approximating the behavior of $I(\phi)$ by a simple volume fraction average

$$
I(\phi)=\phi_{\mathrm{A}} I_{\mathrm{A}}^{0}+\phi_{\mathrm{S}} I_{\mathrm{S}}
$$

may be justified. The simplicity of Equation 4 is quite appealing as it requires only the stationary phase composition and the retention indices of the solute on each pure solvent. Comparison of Equations 1 and 4 does not readily reveal when the two expressions are identical.

The "apparent" success of Equation 4 is perhaps better understood when the partition coefficients in binary systems are described with a realistic thermodynamic model. Acree and Bertrand (2) expressed the partition coefficient of a solute (at infinite dilution) in noncomplexing binary systems as

$$
\begin{aligned}
& \ln K_{\mathrm{R}(\mathrm{X})}^{0}= \\
& \phi_{\mathrm{A}} \ln K_{\mathrm{R}(\mathrm{X}), \mathrm{A}}^{0}+\phi_{\mathrm{S}} \ln K_{\mathrm{R}(\mathrm{X}), \mathrm{S}}^{0}+\frac{\bar{V}_{\mathrm{X}} \Delta \bar{G}_{\mathrm{AS}}^{\mathrm{fh}}}{R T\left(X_{\mathrm{A}} \bar{V}_{\mathrm{A}}+X_{\mathrm{S}} \bar{V}_{\mathrm{S}}\right)}
\end{aligned}
$$

in which $\bar{V}_{i}$ represents the molar volume of component $i$ and $\Delta \bar{G}_{\mathrm{AS}}^{\mathrm{fh}}$ is the excess Gibbs free energy (relative to Flory-Huggins entropy) per mole of the binary mixture of components $A$ and $\mathrm{S}$ (Ref. 2, Equation 18). If the molar volume of the solute is small in comparison to the solvent and/or the free energy of the solvent pair is small, the last term on the right-hand side of Equation 5 is negligible.

The Kovats' retention index for a component $\mathrm{X}$ is related to the partition coefficient by 


$$
I=100 \frac{\log \left(K_{\mathrm{R}(\mathrm{X})} / K_{\mathrm{R}(\mathrm{Z})}\right)}{\log \left(K_{\mathrm{R}(\mathrm{Z}+1)} / K_{\mathrm{R}(\mathrm{Z})}\right)}+100 Z
$$

where $\mathrm{Z}$ is an $n$-paraffin with $Z$ carbon atoms. The partition coefficients of the solute and the two reference $n$-paraffins in binary mixtures can be predicted through Equation 5, and when combined into Equation 6 yield:

$$
\begin{aligned}
& I(\phi)= 100\left[\phi_{\mathrm{A}} \ln \left(\frac{K_{\mathrm{R}(\mathrm{X}), \mathrm{A}}^{\mathrm{A}}}{K_{\mathrm{R}(\mathrm{Z}), \mathrm{A}}^{0}}\right)+\phi_{\mathrm{S}} \ln \left(\frac{K_{\mathrm{R}(\mathrm{X}), \mathrm{S}}^{0}}{K_{\mathrm{R}(\mathrm{Z}) \mathrm{S}}^{0}}\right)+\right. \\
&\left.\frac{\bar{V}_{\mathrm{X}}-\bar{V}_{\mathrm{Z}}}{\left(X_{\mathrm{A}} \bar{V}_{\mathrm{A}}+X_{\mathrm{S}} \bar{V}_{\mathrm{S}}\right)} \frac{\Delta \bar{G}_{\mathrm{AS}}^{\mathrm{fh}}}{R T}\right]\left[\phi_{\mathrm{A}} \ln \left(\frac{K_{\mathrm{R}(\mathrm{Z}+1), \mathrm{A}}^{0}}{K_{\mathrm{R}(\mathrm{Z}), \mathrm{A}}^{0}}\right)+\right. \\
&\left.\phi_{\mathrm{S}} \ln \left(\frac{K_{\mathrm{R}(\mathrm{Z}+1), \mathrm{S}}^{0}}{K_{\mathrm{R}(\mathrm{Z}), \mathrm{S}}^{0}}\right)+\frac{\left(\bar{V}_{\mathrm{Z}+1}-\bar{V}_{\mathrm{Z}}\right)}{\left(X_{\mathrm{A}} \bar{V}_{\mathrm{A}}+X_{\mathrm{S}} \bar{V}_{\mathrm{S}}\right)} \frac{\Delta \bar{G}_{\mathrm{AS}}^{\mathrm{fh}}}{R T}\right]^{-1}+100 Z
\end{aligned}
$$

The two terms involving $\Delta \bar{G}_{\mathrm{AS}}^{\text {fh }}$ will normally be negligible as the difference in molar volumes $\left(\bar{V}_{i}-\bar{V}_{j}\right)$ will be quite small. Neglect of the terms involving $\Delta \bar{G}_{A S}^{\text {th }}$ allows the Kovats' re. tention index in mixtures to be expressed as a weighted av. erage of the indices in the pure solvents $\left(I_{\mathrm{A}}^{0}, I_{\mathrm{S}}^{0}\right)$

$$
I(\phi)=g_{\mathrm{A}} I_{\mathrm{A}}^{0}+g_{\mathrm{S}} I_{\mathrm{S}}^{0}
$$

$$
\begin{array}{r}
g_{\mathrm{A}}=\left(\frac{K_{\mathrm{R}(\mathrm{Z}+1), \mathrm{A}}^{0}}{K_{\mathrm{R}(\mathrm{Z}), \mathrm{A}}^{0}}\right) /\left[\phi_{\mathrm{A}} \log \left(\frac{K_{\mathrm{R}(\mathrm{Z}+1), \mathrm{A}}^{0}}{K_{\mathrm{R}(\mathrm{Z}), \mathrm{A}}^{0}}\right)+\right. \\
\left.\phi_{\mathrm{S}} \log \left(\frac{K_{\mathrm{R}(\mathrm{Z}+1), \mathrm{S}}^{0}}{K_{\mathrm{R}(\mathrm{Z}) \mathrm{S}}^{0}}\right)\right]=1-g_{\mathrm{S}}(9)
\end{array}
$$

For systems in which

$$
\ln \left(K_{\mathrm{R}(\mathrm{Z}+1), \mathrm{A}}^{0} / K_{\mathrm{R}(\mathrm{Z}), \mathrm{A}}^{0}\right)=\ln \left(K_{\mathrm{R}(\mathrm{Z}+1), \mathrm{S}}^{0} / K_{\mathrm{R}(\mathrm{Z}), \mathrm{S}}^{0}\right)
$$

Equation 8 is identical to Equation 4 and plots of $I$ vs. $\phi$ would be linear.

Inspection of the experimental data for the squalane + di-n-nonyl phthalate solvent systems (1) reveals that partition coefficients in binary mixtures are reasonably estimated $(1-2 \%)$ through Equation $5,\left[\Delta \bar{G}_{A S}^{\text {h }}=0\right]$, for all solutes with the exception of ethoxybenzene, benzaldehyde, and acetophenone. Graphical comparison of the experimental and calculated values is shown in Figure 1 for several solutes. Slight improvements were noted if the experimental partition coefficients of the alkanes (generally considered incapable of forming association complexes) are used to calculate an average $\Delta \bar{G}_{A S}^{\text {fh }}$ at each composition, and this value is incorporated into the calculations. Complexation between the solute and one solvent component

$$
\mathrm{X}+\mathrm{S}=\mathrm{XS}
$$

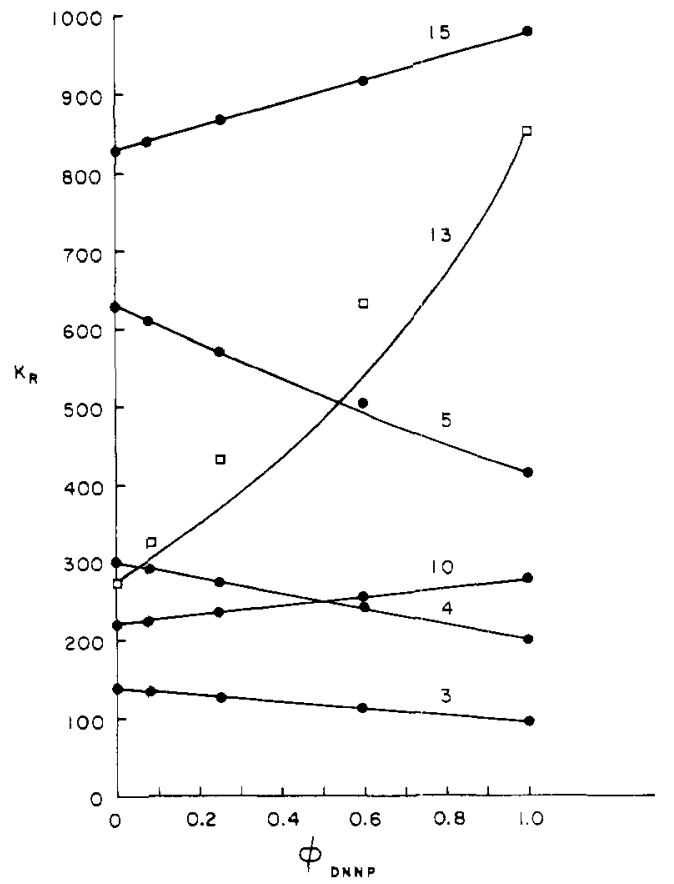

Figure 1. Dependence of $K_{\mathrm{R}}$ on the volume fraction of di- $n$-nonyl phthalate in mixtures with squalane. Plotted points represent data from Ref. 1 and solid lines are calculated from Equation 5 with $\Delta \bar{G}_{A S}^{\text {th }}=0$. The solutes are octane (3), nonane (4), decane (5), p-xylene (10), benzaldehyde (13), and butylbenzene (15)

can lead to the failure of Equation 5 in which case an extended form including an equilibrium constant (2)

$$
\begin{aligned}
\ln K_{\mathrm{R}(\mathrm{X})}^{0} & =\phi_{\mathrm{A}} \ln K_{\mathrm{R}(\mathrm{X}), \mathrm{A}}^{0}+\phi_{\mathrm{S}} \ln K_{\mathrm{R}(\mathrm{X}), \mathrm{S}}^{\mathrm{S}}+ \\
& \ln \left(1+K^{\prime} \phi_{\mathrm{S}}\right)-\phi_{\mathrm{S}} \ln \left(1+K^{\prime}\right)+\frac{\bar{V}_{\mathrm{X}} \Delta \bar{G}_{\mathrm{AS}}^{\mathrm{fh}}}{\left(X_{\mathrm{A}} \bar{V}_{\mathrm{A}}+X_{\mathrm{S}} \bar{V}_{\mathrm{S}}\right) R T}
\end{aligned}
$$

should be more appropriate. While simple linear relationships between volume fraction and partition coefficients, such as

$$
K_{\mathrm{R}(\mathrm{X})}^{0}=\phi_{\mathrm{A}} K_{\mathrm{R}(\mathrm{X}), \mathrm{A}}^{0}+\phi_{\mathrm{S}} K_{\mathrm{R}(\mathrm{X}), \mathrm{S}}^{0}
$$

may provide reasonable estimates for many systems studied to date, meaningful association constants cannot be calculated directly from Equation 12 since this expression applies equally well to both complexing and noncomplexing systems.

\section{LITERATURE CITED}

(1) Pecsok, R. L.; Apffel, J. Anal. Chem. 1979, 51, 594.

(2) Acree, W. E., Jr.; Bertrand, G. L. J. Phys. Chem. 1979, 83, 2355.

William E. Acree, Jr.

Department of Pharmaceutical Chemistry

J. Howard Rytting*

The University of Kansas

Lawrence, Kansas 66045

RECEIVED for review February 19, 1980. Accepted May 12, 1980. Supported in part by National Institutes of Health Grant GM22357. 